\title{
FORMULATION DEVELOPMENT AND PHYSICAL TEST OF LEAF ETHANOL EXTRACT CREAM NONI (Morinda Citrifolia L) AS A WOUND HEALER
}

\author{
Anom Parmadi ${ }^{1}$, Sri Rejeki ${ }^{2}$, Siwi Hastuti ${ }^{3}$ \\ ${ }^{1}$ Poltekkes Bhakti Mulia Sukoharjo \\ ${ }^{2}$ Poltekkes Bhakti Mulia Sukoharjo \\ 3Poltekkes Bhakti Mulia Sukoharjo \\ Corresponding author : anomparmadi13@gmail.com
}

\begin{abstract}
Injuries are lost or damaged part of the body's tissues. Wounds are also defined as physical damage due to the opening or destruction of the skin which can cause abnormal skin function and anatomy. These plants widely used traditionally from fresh noni leaves used as a medicine for broken bones, cuts, burns and pain by boiling and drinking the juice. These studys to make use of more effective and efficient Noni leaf extract made in cream preparations as a wound medicine, so that people are easy to use. This study used an experimental research method, namely the cream formulation of noni concentrated ethanol extract of $5 \%, 10 \%$ and $15 \%$. Cream preparation evaluation test included: Organoleptic, $\mathrm{pH}$ test, cream type test, homogeneity test, sticky power test, dispersion test and protection power test. The test method was carried out on mice by means of cream preparations applied to the back of mice which were given an incision wound. Its effectiveness is seen from the measurement of wound length for seven days to calculate the percentage of wound healing power. The results of the One Way ANOVA test showed that there were significant differences between concentrations of $5 \%, 10 \%$ and $15 \%$ with significant values $<0.05$. The percentage of healing power of noni leaf extract cream concentration of $5 \%=7,69 \%$, concentration of $10 \%=17,26 \%$, and concentration of $15 \%=29,35 \%$. The results showed that the ethanol extract of noni leaves can be made in cream dosage form and has the effectiveness to accelerate the healing of incision wounds in mice.
\end{abstract}

\section{Keywords: Noni Leaf Extract, Morinda citrifolia, Cream, Wound Healing}

\section{Intoduction}

For a long time humans used plants and natural ingredients as a medicine to reduce pain, heal, and prevent certain diseases, beautify themselves and maintain the condition of the body to stay healthy and fit. The use of traditional medicine as an alternative treatment has long been carried out long before there was formal health service using modern medicines. Traditional medicine is a product made from natural ingredients whose types and properties are very diverse and hereditary have been used for treatment based on experience (Dirjen POM, 2007).

One of the medicinal plants that is often used by people is mengkudu (Morinda citrifolia L) which is internationally known as "noni" which is a typical term of Hawaiian people. Noni contains various substances that are very useful for curing diseases. Benefits of noni include wound healing, anti-bacterial, analgesic, immunomodulatory, antiinflammatory, anti-ulcer, diabetes, cancer, high blood pressure, etc. (Abbott, 1992).

Noni chemical content is as follows: scopoletin, octanoic acid, potassium, ascorbic acid, triterpenoids, alkaloids, anthraquinones, sitosterol, beta carotene, vitamin A, flavonoid glycosides and linoleic acid (Rasal et al., 2008), saponins (Satwadhar et al ., 2011), tannins (Nayak et al., 2009), xeronin (Peter, 2007).

Traditionally noni fresh leaves are used as medicine for fractures, deep cuts or deep cuts, burns and pain (Rasal et al., 2008). Noni contains substances that can accelerate the process of wound healing, among others: Proxeronine (cell regeneration and hormonal balance), scopoletin (anti-bacterial and anti-inflammatory), anthraquinone (anti-bacterial), phytonutrients and selenium (anti-oxidants), acids essential amino acids, vitamin $\mathrm{C}$ and vitamin $\mathrm{A}$, flavonoids 
(flavonoid glycosides), terpenoids, xeronine, acubin, L-asperuloside, and alizarin (Rassal et al., 2008).

Noni (M. citrifolia) is one of the medicinal plants that in the last few years many enthusiasts both from the agribusiness entrepreneurs, and from the entrepreneurs of the traditional medicine industry, even among scientists in various countries. This is because both empirically and the results of medical research prove that in all parts of the noni plant contains various kinds of chemical compounds that are useful for human health. The role of noni in traditional medicine encourages researchers in various parts of the world to conduct various studies regarding the efficacy of noni. The popularity of these plants continues to spread to developed countries such as the United States, Britain, France, Australia, Japan and Singapore. Processing industry made from noni raw materials continues to grow in various countries (Djauhariya et al., 2004).

Injuries are lost or damaged part of the body's tissues. Wounds are also defined as physical damage due to the opening or destruction of the skin which can cause an imbalance of normal skin function and anatomy (Nagori and Solanki, 2011). Injuries can be caused by several factors, including sharp or blunt object trauma, explosions, chemicals, changes in temperature, electric shock, animal bites. The wound causes the opening of the skin as one of the body's defense systems, which results in bleeding as well as opening the entrance for bacteria, fungi, viruses into the body and also causes inflammation.

Wound healing is a complex process involving continuous interaction between cells and cells and between cells with a matrix summarized in three overlapping phases. The three phases of wound healing mechanisms that occur are the inflammatory phase (0-3 days), proliferation phase and tissue formation (3-14 days) (Reddy et al., 2012) and the tissue remodeling phase (can be started on day 8 and last until with 1 year) (Broughton et al., 2006).

The wound healing process depends on the extent and depth of the wound, and the presence or absence of complications that interfere with the course of the natural wound healing process. Disorders in the process of tissue repair cause the healing process of old wounds to occur in various conditions such as elderly people, treatment with steroids, and those suffering from diabetes and cancer (Gurtner et al., 2007).

\section{Methods}

This research was conducted at the Laboratory of D3 Pharmacy Study Program of Bhakti Mulia Sukoharjo Health Polytechnic. This research was an experimental study with a Simple Random Sampling approach. Simplicia which is used for making cream of ethanol extract of noni leaf extracted in the Sukoharjo area, noni leaf which is used as a sample of leaves that are still fresh and have criteria, namely the leaves have a length of $10 \mathrm{~cm}-30 \mathrm{~cm}$, width $5 \mathrm{~cm}-17 \mathrm{~cm}$, green as much as 300 grams While the test animals used were male mice that had no anatomical defect criteria, had an age of approximately 5 weeks and weighed $20-30$ g. 25 test animals were used. The method of sampling with the technique of Simple Random Sampling because members of the population have been homogeneous, meaning that samples of mice test animals with the same type and method of supply, so it has the same opportunity to be selected as a sample.

Data obtained in the form of long cuts in mice at certain times. The length of wound healing is calculated from the difference in wound length after and before wound testing.

Long wound healing formula:

$$
\mathrm{Pl}=\mathrm{Po}-\mathrm{Pt}
$$

Keterangan :

Pl: Long healing of incision wounds mice at certain times

Pt: The length of the mice cut after being given treatment

Po: The length of the mice cuts before treated

The length of data for healing the wound was then searched for AUC (Area Under Curve), namely the area under the curve between the average length of wound healing for the time of observation. AUC is calculated from the average wound length of day 0 to day 7 . Calculation of AUC values with the trapezoid method.

Formula :

$$
\underset{\mathrm{tn}-1}{\mathrm{tn}}=\frac{\mathrm{Ptn}-1+\mathrm{Ptn}}{2}(\mathrm{tn}-\mathrm{tn}-1)
$$

Information :

Ptn-1 : The average length of wound healing intn -1

Ptn : Length of average wound healing at tn 
Percent of wound healing power is calculated by formulation:

$$
\% \mathrm{DPL}=\frac{\mathrm{AUC} \mathrm{C}_{K}-\mathrm{AUCP}}{\mathrm{AUC} C_{K}} \times 100 \%
$$

Information :

$\%$ DPL : Percent of Wound Healing Power

$A_{\mathrm{UUC}}$ :AUC long wound healing curve averages against time for negative controls

$A_{\mathrm{P}}$ : AUC long wound healing curves for time for treatment groups in each individual (Haryoto et all., 2010)

The results of the study will be analyzed whether the data has a normal distribution ( $\mathrm{p}>$ 0.05 ) or not statistically by the Kolmogorov Smirnov normality test. If the data variance is normally distributed, followed by repeated ANOVA (Analysis Of Variant) parametric test method and assess the comparison of measurements by post-hoc paired wise comparison using SPSS 16.0 for windows with a $95 \%$ confidence level, $\alpha=0.05$ with a data hypothesis where $\mathrm{H} 0$ there was no difference in the length of the incision wounds and H1 there was a difference in the length of the incision wounds in mice.

\section{Results And Discussion}

\section{Results of Noni Leaf Maseration}

a. Organoleptic

Form : thick extract

Color : Blackish green

Odor : Aromatic of nonileaves

Taste : Bitterb

b. Rendemen Results

$$
\begin{aligned}
\text { Rendemen } & =\frac{\text { Maseration Result }(\mathrm{g})}{\text { Weight Simplicia }(\mathrm{g})} \times 100 \% \\
& =\frac{20,04 \mathrm{~g}}{300 \mathrm{~g}} \times 100 \% \\
& =6,68 \% \mathrm{~b} / \mathrm{b}
\end{aligned}
$$

2. Preparation of Cream Ethanol Leaf ExtractNoni

a. Cream dosage weight produced

Cream preparation concentration of $5 \%=$ $20,00 \mathrm{~g}$

Cream preparation concentration of $10 \%=$ $20,00 \mathrm{~g}$

Cream preparation concentration of $15 \%=$

\begin{tabular}{|c|c|c|c|}
\hline Evaluation test & $\begin{array}{l}\text { Consentration } \\
5 \%\end{array}$ & Consentration $10 \%$ & Consentration $15 \%$ \\
\hline $\begin{array}{cc}\text { Organoleptic } \\
\text { a. } & \text { Form } \\
\text { b. } & \text { Color } \\
\text { c. } & \text { Smell }\end{array}$ & $\begin{array}{l}\text { Semi solid } \\
\text { Black green } \\
\text { Aromaof Jasmine }\end{array}$ & $\begin{array}{l}\text { Semi solid } \\
\text { Black green } \\
\text { Aromaof Jasmine }\end{array}$ & $\begin{array}{l}\text { Semi solid } \\
\text { Blackish Green } \\
\text { Aromaof Jasmine }\end{array}$ \\
\hline Homogeneity & Homogene & Homogene & Homogene \\
\hline $\mathrm{pH}$ test & 6 & 6 & 6 \\
\hline $\begin{array}{l}\text { The protective } \\
\text { power }\end{array}$ & $\begin{array}{l}\text { The cream provides } \\
\text { protection against the } \\
\text { effect of the base }\end{array}$ & $\begin{array}{l}\text { The cream provides } \\
\text { protection against the } \\
\text { effect of the base }\end{array}$ & $\begin{array}{l}\text { The cream provides } \\
\text { protection against the } \\
\text { effect of the base }\end{array}$ \\
\hline Tyipe cream & $\mathrm{W} / \mathrm{O}$ & $\mathrm{W} / \mathrm{O}$ & $\mathrm{W} / \mathrm{O}$ \\
\hline
\end{tabular}
20,00

b. Evaluation test of cream preparations of noni leaf ethanol extract

Table 1. Analysis of Evaluation Results of Cream Preparation of Noni Leaf Ethanol Extract

Table 1 . The results of each cream of noni leaf ethanol extract $5 \%, 10 \%$ and $15 \%$ are as follows:

a) Organoleptic test: cream of ethanol extract of $5 \%$ noni leaf in semi solid form, blackish green

Volume 1 Issue 1 (2018) color and smell of aromatic jasmine. The cream of $10 \%$ noni extract in the form of semi solid, blackish green color and smells of aromatic jasmine, while the cream of $15 \%$ noni 
leaf extract is semi solid, greenish black and smells of aromatic jasmine. Organoleptic test is done to observe: the shape, color, smell and taste of the cream preparation.

b) Homogeneity test: the results of testing the homogeneity of cream of $5 \%, 10 \%$ and $15 \%$ noni leaf ethanol extracts were obtained homogeneous results, meaning that all active ingredients used in the formulation were evenly dispersed on the cream base.

c) $\mathrm{pH}$ test: $\mathrm{pH}$ test results of cream preparations of noni leaf ethanol extract obtained from the $\mathrm{pH}$ of the preparation 6 . In testing the $\mathrm{pH}$ of the cream must be adjusted to the $\mathrm{pH}$ of human skin that is 4.5 to 6.5 (Anief, 2000), so the $\mathrm{pH}$ test results are in accordance with requirements.

d) Protection power test: from the protective power test shows that the cream provides protection against the basic $\mathrm{NaOH}$ solution because the protection of the cream does not give a red or pink color, this indicates that all preparations can provide protection. Test the protection power to find out whether the cream produced provides protection against the effects of acids, bases and sunlight.

e) Type of cream: cream of ethanol extract of noni leaves $5 \%, 10 \%$ and $15 \%$ using methylene blue solution obtained by cream has a type of cream A / M (Water in Oil) where the water is blue and the oil appears transparent.

Table 2. Results of Cream Scatter Test

a) $5 \%$ concentration

\begin{tabular}{llll}
\hline Replication & $\begin{array}{c}\text { Not load } \\
\left(\mathrm{cm}^{2}\right)\end{array}$ & $\begin{array}{l}\text { without load } \\
50 \text { gram }\left(\mathrm{cm}^{2}\right)\end{array}$ & without load100 gram $\left(\mathrm{cm}^{2}\right)$ \\
\hline I & 12,56 & 17,7115 & 19,625 \\
II & 12,56 & 16,2514 & 19,625 \\
III & 13,1958 & 17,7115 & 20,0194 \\
& 12,7719 & 17,2248 & 19,7564 \\
\hline
\end{tabular}

The results of the cream dispersal power test of $5 \%$ noni leaf extract tested using an extensionometer obtained an average dispersion of cream without load was 12.7719 $\mathrm{cm}^{2}, 50$ gram load was $17.2248 \mathrm{~cm}^{2}$ and with a load of 100 grams was $19.7564 \mathrm{~cm}^{2}$.

b) Concetration $10 \%$

\begin{tabular}{cccc}
\hline Replication & $\begin{array}{c}\text { Not load } \\
\left(\mathrm{cm}^{2}\right)\end{array}$ & $\begin{array}{c}\text { without load } \\
50 \text { gram }\left(\mathrm{cm}^{2}\right)\end{array}$ & $\begin{array}{c}\text { without load } 100 \\
\text { gram }\left(\mathrm{cm}^{2}\right)\end{array}$ \\
\hline I & 7,5438 & 9,6162 & 11,6356 \\
II & 7,5438 & 10,1736 & 11,9398 \\
III & 7,3024 & 10,4581 & 13,1958 \\
$\overline{\mathrm{x}}$ & 7,4633 & 10,0826 & 12,2570
\end{tabular}

The results of the cream dispersion test of $10 \%$ Morinda citrifolia leaf extract tested using an extensionometer obtained an average no-load cream dispersion was 7.4633 $\mathrm{cm}^{2}, 50$ gram load was $10.0826 \mathrm{~cm}^{2}$ and with a load of 100 grams was $12.2570 \mathrm{~cm}^{2}$. 
c) Concentration $15 \%$

\begin{tabular}{|c|c|c|c|}
\hline Replication & $\begin{array}{l}\text { Not load } \\
\left(\mathrm{cm}^{2}\right)\end{array}$ & $\begin{array}{l}\text { without load } \\
50 \operatorname{gram}\left(\mathrm{cm}^{2}\right)\end{array}$ & $\begin{array}{l}\text { without load } 100 \\
\operatorname{gram}\left(\mathrm{cm}^{2}\right)\end{array}$ \\
\hline I & 5,9365 & 7,3024 & 8,8096 \\
\hline II & 5,7226 & 7,0650 & 8,8096 \\
\hline III & 5,5126 & 7,3024 & 8,8096 \\
\hline$\overline{\mathrm{x}}$ & 5,7239 & 7,2232 & 8,8096 \\
\hline
\end{tabular}

The results of the cream dispersion test of $15 \%$ Morinda citrifolia ethanol extract tested using an extensionometer obtained an average load-bearing cream without load was $5,7239 \mathrm{~cm}^{2}, 50 \mathrm{gram}$ load was $7,2232 \mathrm{~cm}^{2}$ and with a load of 100 grams was $8,8096 \mathrm{~cm}^{2}$.

Spread power test to determine the level of dispersion of the cream on the skin, the results obtained show that the more the concentration of cream is used, the lower the value of the dispersion power at each concentration.

Table 3. The results of the cream adhesion test

\begin{tabular}{ccccc}
\hline \multirow{2}{*}{ Extract Cream } & \multicolumn{3}{c}{ Adhesion Test (second) } \\
& Replication I & Replication II & Replication III & Average \\
\hline Concentration $5 \%$ & 5,29 & 5,53 & 5,28 & 5,36 \\
Concentration10\% & 4,21 & 4,17 & 4,30 & 4,22 \\
Concentration15\% & 4,04 & 4,16 & 4,22 & 4,14 \\
\hline
\end{tabular}

The adhesion test results of cream $5 \%$, $10 \%$ and $15 \%$ of noni leaf ethanol extract obtained the average adhesion strength of $5 \%$ noni leaf extract of ethanol extract was 5.36 seconds, the cream ethanol extract of noni leaves $10 \%$ was 4.22 seconds and cream of $15 \%$ noni leaf ethanol extract is 4.14 seconds. This stickiness test aims to determine the ability of the cream to attach to the skin.

Table 4. Results of Average AUC Results (Area Under Curve) and Average Percentage of Wound Healing Power between Treatment Groups.

\begin{tabular}{llcc}
\hline \multirow{2}{*}{ No } & \multicolumn{1}{c}{ Test Requirements } & Average AUC \pm SEM & (Average DPL \pm SEM) $\%$ \\
\hline 1) & Negative controle (basiccream) & $6,37 \pm 0,1098$ & 0 \\
2) & Positive controle (sagestam ${ }^{\circledR}$ cream) & $3,28 \pm 0,1604$ & $48,502 \pm 2,08$ \\
3) & Cream ethanol extract of noni leaves 5\% & $5,88 \pm 0,1318$ & $7,686 \pm 1,18$ \\
4) & Cream ethanol extract of noni leaves 10\% & $5,27 \pm 0,127$ & $17,264 \pm 1,86$ \\
5) & Cream ethanol extract of noni leaves 15\% & $4,5 \pm 0,1407$ & $29,354 \pm 3,31$ \\
\hline
\end{tabular}




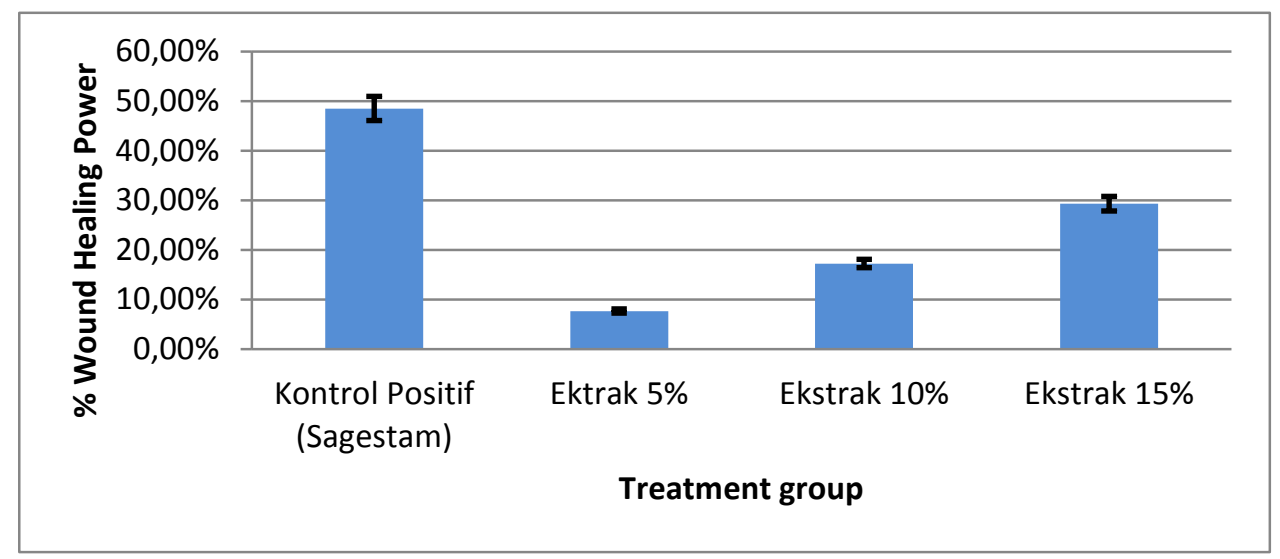

AUC (Area Under Curve) is used to determine the percentage of wound healing power from several treatments then compared between treatments. The percentage of wound healing power between treatment groups is shown in Figure 2. The results of the positive control group were $48.50 \%, 5 \%$ extract concentration was $7,69 \%, 10 \%$ extract concentration was $17,26 \%$, extract concentration $15 \%$ was $29,35 \%$.

Cream is a semi-solid preparation containing not less than $60 \%$ water and is intended for external use (Dirjen POM, 1979). The cream making of noni leaf ethanol extract aims to make cream preparations from noni leaf extract and provide information to the public that cream preparations can be made to treat wounds.

Maseration is one of the methods of extraction that has the advantage of being in a simple way of working, the equipment used is simple and easy to use so that the required costs are small. This method is used because the compounds contained in noni leaves can dissolve in ethanol. Noni contains various substances that are very useful for curing diseases. Benefits of noni include wound healing, anti-bacterial, analgesic, immunomodulatory, anti-inflammatory, antiulcer, diabetes, cancer, high blood pressure, etc. (Abbott, 1992).

The base used in this cream preparation is cleansing cream because this base is difficult to be washed with water so that it is expected that direct contact between the cream or medicine with the wound can be longer so that the cream has the maximum therapeutic effect.

A preparation is said to be good and safe to use after the testing phase. This cream test consisted of organoleptic test, homogeneity test, $\mathrm{pH}$ test, dispersion test, stickiness test, protection power test and cream type.

An incision is a type of wound caused by an incision from a sharp object, metal or wood. In this study the test animals were slashed using a knife and the length of the incision was measured using a measuring instrument, before the mice were coated with cream base as a negative control, sagestam ${ }^{\circledR}$ cream (gentamycin cream) as a positive control and cream of noni extract for seven days.

Wound length measurements from all treatment groups from day 1 to day 7 where the wound length gradually healed until day 7 . Very significant data obtained was shown in the sagestam ${ }^{\circledR}$ cream treatment group (positive control) with 15\% noni leaf ethanol extract cream compared to the basic treatment group of cream. That means the cream of noni leaf ethanol extract which basically contains alkaloids, saponins and flavonoids works well so it can heal wounds. Positive control uses sagestam ${ }^{\circledR}$ cream (gentamycin cream) because it contains the active ingredient gentamycin cream which can cure skin infections caused by bacteria.

Kolmogorov-Smirnov test results on the percentage of healing power of incision wounds in mice for seven days obtained results of data normality test obtained values (sig $>0.05$ ) then the data is normally distributed. The results of statistical tests using the One Way ANOVA (Analysis Of Variant) test obtained the value $(\operatorname{sig} 0,000)$ which means that the value of $\mathrm{P}<0.05$ then $\mathrm{H} 0$ is rejected and $\mathrm{H} 1$ is accepted so that there is a significant difference between the five treatment groups of test animals. Based on the test, it can be continued with the LSD (Least Significant Different) test.

The LSD (Least Significant Different) test is used to see whether each treatment has a significant difference or not and this LSD test is to see which treatment has an effect. LSD test results obtained values (sig <0.05) then $\mathrm{H} 0$ was rejected, so there was a significant difference between the five treatments of mice test animals, it means that between the cream ethanol extract of noni leaves $5 \%, 10 \%, 15 \%$ and positive control (sagestam ${ }^{\circledR}$ cream ) both provide the results of wound healing in mice.

Results of AUC (Area Under Curve) percentage of healing ability of cream wound ethanol 
extract of noni leaves $5 \%, 10 \%$ and $15 \%$ respectively had a percentage of effectiveness of wound healing power $(7,69 \pm 1,18) \%,(17,26 \pm 1,86) \%,(29,35 \pm$ $3,31) \%$, which means that the cream of ethanol extract of noni leaves is efficacious to accelerate wound healing, this supports the research of Winny Ambiyani (2013) Pemberian Salep Ekstrak Daun Mengkudu (Morinda citrifolia L) Meningkatkan Proses Regenerasi Jaringan Luka Pada Tikus Putih Jalur Wistar (Rattus norvegicus) Jantan.

\section{Conclusion}

Ethanol extract of noni leaves (Morinda citrifolia L) can be made cream dosage form and fulfill the evaluation requirements of cream preparations. Percentage of wound healing power Cream $5 \%$ of noni leaf extract of $7,69 \%, 10 \%$ concentration of $17,26 \%$ and $15 \%$ concentration of $29,35 \%$, which means the cream of ethanol extract of noni leaves has positive results on wound healing in mice .

\section{References}

Abbott, I. A. 1992. La'au Hawaii: Traditional Hawaiian uses of plants. Honolulu. Hawaii: Bishop Museum.

Ambiyani, Winny. 2013.) Pemberian Salep Ekstrak Daun Mengkudu (Morinda citrifolia L) Meningkatkan Proses Regenerasi Jaringan Luka Pada Tikus Putih Jalur Wistar (Rattus norvegicus) Jantan. Tesis.Udayana University Denpasar.

Anief, M. 2000. Farmasetika. Yogyakarta : Gadjah Mada University Press

Broughton II, G., Janis, J.E., Attiger, C.E. 2006. Wound healing : an overview. Plastic Reconstruction Surgery 117 (supplement) : 1eS-32Es

Direktorat Jendral Pengawasan Obat dan Makanan. 1995. Farmakope Indonesia Edisi IV. Jakarta : Ministry of Health of the Republic Indonesia

Direktorat Jendral Badan Pengawasan Obat dan Makanan. 2007. Lampiran Keputusan Menteri Kesehatan Nomor : 381/Menkes/ SK/III/2007 mengenai Kebijakan Obat Tradisional Nasional.
Jakarta : Ministry of Health of the Republic Indonesia

Djauhariya, E., Hera, N. dan M. Rahardjo, 2004. Effect of Growth Regulating Substances and Graft Media on the Success of Noni Plant Grafting.Tawangmangu : Pros. Seminar Nasional XXV TOI : 104 - 110.

Haryoto., Yuliati, K. S., Wahyuningtyas, N. 2010. AntiInflammation Effect of Groundnut Skin Ethanol Extract (Arachis bypogaea L.) on Swiss Strain Male White Mice Induced by Caragenine. JFI PharmaconPharmaceutical Jurnal ofIndonesia. 11 (1) : $7-12$

Nagori, B.D. and Solanki, R. 2011. Role of Medicinal Plants in Wound Healing. Research Journal of Medicinal Plant 5 (4). p. 392-405

Nayak BS, Sandiford S, Maxwell A, 2009. Evaluation of wound healing activity of ethanolic extract of Morinda citrifolia L. Leaf. Evid Cased Alternat Med. $6: 351-356$

Peter, P.I. 2007. Clinical Research on Morinda citrifolia L. Noni Clinical Research Journal. Vol: 1. Numbers 1-2. p. 4-10

Rasal, V.P., Sinnathambi, A., Ashok, P., Yeshmaina, S. 2008. Wound Healing and Antioxidant Activities of Morinda citrifolia Leaf Extract in Rats. Iranian Journal of Pharmacology \& Therapeutics. Vol: 7, No. 1. p. 49-52

Reddy, G.A.K., Priyanka, B., Saranya, Ch.S., Kumar, C.K.A. 2012. Wound Healing Potential Of Indian Medicinal Plants. International Journal of Pharmacy Review \& Research. Vol: 2. p. 75-78

Satwadhar, P.N., Deshpande, H.W., Syed, I.H., Syed K.A. 2011. Nutritional Composition and Identificaataion of Some of The Bioactive Components inMorinda Citrifolia Juice. International Journal of Pharmacy and Pharmaceutical Sciences. Vol: 3, Issue1. p. 58-60 